\title{
First record of piebaldism in the Munoa worm lizard (Amphisbaena munoai)
}

\author{
RENATA PEREZ* \& DIEGO J. ALVARES
}

\begin{abstract}
Programa de Pós-graduação em Biologia Animal, Laboratório de Herpetologia, Universidade Federal do Rio Grande do Sul, Av. Bento Gonçalves, 9500, Campus do Vale, prédio 43435, sala 102, 91501-970, Porto Alegre, RS, Brazil

*Corresponding author e-mail: renattaperez@gmail.com
\end{abstract}

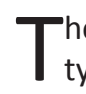
he pigmentation of reptiles is determined by the different types of chromatophore embedded within the skin. Chromatic anomalies are not uncommon and result from the inactivity or the absence of one or more chromatophores types (Prüst, 1984; Bechtel, 1991). The terminology for such anomalies tends to be confused. The anomaly most frequently reported in the literature is hypopigmentation since this is the easiest to detected (Kazilas et al., 2018; Kornilios, 2014; Lucati \& López-Baucells, 2017; Zalapa et al., 2016). One form of hypopigmentation is albinism which refers to the complete absence of pigment in the skin or eyes (Prüst, 1984; Bechtel, 1991). When the absence of pigment isn't total, the term 'partial albinism' is used, nevertheless this condition can be better classified as leucism or piebaldism (Prüst, 1984; Bechtel, 1991; Lucati \& López-Baucells, 2017). Leucism refers to absence of any skin pigment, except in the eyes; while piebald specimens have coloured eyes and lack pigments only on some parts of the body, frequently resulting in spotted colour patterns (Prüst, 1984; Bechtel, 1991; Grouw, 2006, 2013; Abreu et al., 2013; Fertl \& Rosel, 2009).

In this report we present the first record of piebaldism in Amphisbaena munoai Klappenbach 1960 (Amphisbaenidae). This is a small and slender worm-lizard distributed in areas of the Uruguayan savannah ecoregion that comprises subtropical open areas of southern South America, in the Brazilian state of Rio Grande do Sul and eastern Uruguay (Dinerstein et al., 2017). The species reaches $151 \mathrm{~mm}$ snoutvent length (102 $\mathrm{mm}$ to $151 \mathrm{~mm}$ in adults) and normally has a light brown colour that is intense dorsally, extends laterally and then fades in the center of the ventral region (Perez \& Borges-Martins, 2019).

During a field survey on 27th October 2015, in the municipality of Bagé (Rio Grande do Sul, Brazil) we encountered two specimens of $A$. munoai under a fallen tree trunk in an open field (-54.0189 longitude, -31.3195 latitude: WGS84). These have been deposited as voucher specimens in the collection of the Departamento de Zoologia, Universidade Federal do Rio Grande do Sul (UFRGS). One of the specimens (UFRGS 7417) was piebald (Fig. 1) while the other (UFRGS 7418) had quite normal coloration. The piebald amphisbaenian was a juvenile and had a snout vent length of $97 \mathrm{~mm}$ and a tail length of $12 \mathrm{~mm}$. The eyes had coloration typical for this species but the body had nonpigmented areas giving a typical piebald pattern (Fig. 1).

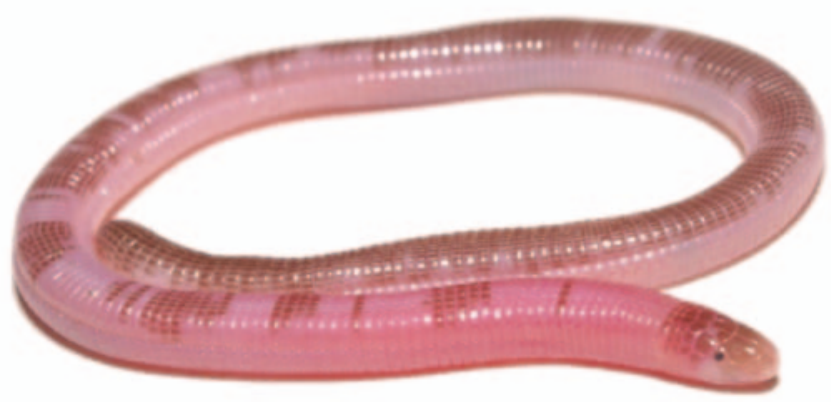

Figure 1. Piebald specimen of Amphisbaena munoai (UFRGS 7417) from Bagé municipality, Rio Grande do Sul, Brazil

There are three earlier records of pigment deficiency in amphisbaenians. A case of piebaldism was recorded as partial albinism in Amphisbaena trachura (Chalkidis \& Di-Bernardo, 2004), and cases of piebaldism have been reported in Blanus strauchi (Kazilas et al., 2018) and Blanus cinereus (Malkmus, 1997). Reptiles with chromatic anomalies are normally rare in nature, mostly because there are associated with defective vision, an inability to thermoregulate, or they are easily predated (Krecsak, 2008; Hupfeld \& Hoffmann, 2006; Kornilios, 2014). However, as amphisbaenians are fossorial species these problems may not affect their ability to survive (Kornilios, 2014; Kazilas et al., 2018) and so may increase the frequency with which this abnormality is observed in nature.

\section{ACKNOWLEDGEMENTS}

RP thank Coordenação de Aperfeiçoamento de Pessoal de Nível Superior (CAPES) and DJA thank Conselho Nacional de Desenvolvimento Científico e Tecnológico (CNPq) for the grants conceded at the time. We also thank Laura Verrastro and Eletrosul for organising and financing the field work.

\section{REFERENCES}

Abreu, M., Machado, R., Barbieri, F., Freitas, N. \& Oliveira, F. (2013). Anomalous colour in neotropical mammals: a review with new records for Didelphis sp. (Didelphidae, Didelphimorphia) and Arctocephalus australis (Otariidae, Carnivora). Brazilian Jounal of Biology 73: 185-194.

Bechtel, H.B. (1991). Inherited color defects: comparison 
between humans and snakes. International Journal of Dermatology 30: 243-246.

Chalkidis, H. de M. \& Di-Bernardo, M. (2004). Amphisbaena darwini trachura (worm lizard) Albinism. Herpetological Review 35:165.

Dinerstein, E., Olson, D., Joshi, A. et al. (2017). An ecoregionbased approach to protecting half the terrestrial realm. Bioscience 67: 534-545.

Fertl, D. \& Rosel, P.E. (2009). Albinism. In Encyclopedia of Marine Mammals. Elsevier, pp. 24-26.

Grouw, H. Van (2006). Not every white bird is an albino: sense and nonsense about colour aberrations in birds. Dutch Birding 28: 79-89.

Grouw, H. Van (2013). What colour is that bird? British Birds: 17-29.

Hupfeld, D. \& Hoffmann, K.P. (2006). Motion perception in rats (Rattus norvegicus sp.): Deficits in albino Wistar rats compared to pigmented Long-Evans rats. Behavioural Brain Research 170: 29-33.

Kazilas, C., Kalaentzis, K. \& Strachinis, I. (2018). A case of piebaldism in the Anatolian Worm Lizard, Blanus strauchi (Bedriaga, 1884), from Kastellorizo Island, Greece (Squamata: Blanidae). Herpetological Notes 11: 527-529. Klappenbach, M.A. (1960). Notas herpetológicas. I. Amphisbaena munoai n. sp. (Amphisbaenidae). Commicacciones en Zoologie do Museo Historia Naturel Montevideo 4: 1-12.
Kornilios, P. (2014). First report of piebaldism in scolecophidians: A case of Typhlops vermicularis (Squamata: Typhlopidae). Herpetological Notes 7: 401-403.

Krecsak, L. (2008). Albinism and leucism among European Viperinae: a review. Russian Journal of Herpetology 15: 97-102.

Lucati, F. \& López-Baucells, A. (2017). Chromatic disorders in bats: a review of pigmentation anomalies and the misuse of terms to describe them. Mammal Review 47: 112-123.

Malkmus, R. (1997). Partieller Albinismus bei der Netzwühle, Blanus cinereus (Vandelli, 1797) in Portugal (Reptilia: Amphisbaenidae). Sauria 19: 45-46.

Prüst, E. (1984). Albinism in snakes. Litteratura Serpentium 4: 6-15.

Sazima, I. \& Di-Bernardo, M. (1991). Albinismo em serpentes neotropicais. Memórias do Instituto Butantan 53: 167173.

Zalapa, S.S., Guerrero, S., Romero-Almaraz, M.D.L. \& SánchezHernández, C. (2016). Coloración atípica en murciélagos: frecuencia y fenotipos en Norte y Centroamérica e islas del Caribe y nuevos casos para México y Costa Rica. Revista Mexicana de Biodiversidad 87: 474-482.

Accepted: 3 September 2020 